\title{
Microfinance in Zimbabwe: A Historical Overview
}

\author{
Stephen Mago, PhD. \\ University of Fort Hare, Department of Development Studies, P. Bag X1314, Alice,5700, South Africa. \\ e-mail-stepmago@gmail.com or stephen_mago@yahoo.com
}

\section{Doi:10.5901/mjss.2013.v4n14p599}

\begin{abstract}
The purpose of this paper is to provide a historical overview of microfinance development in Zimbabwe. The paper adopted a historical analysis approach. Information was gathered from secondary sources about microcredit and microfinance. Historical analysis' main advantage is its ability to establish a context or background for us to set a contemporary study in microfinance. Findings show that microfinance is a new phenomenon that evolved from microcredit. Globally, the idea of microcredit dates back to the 15th century. For Zimbabwe, microcredit started in the 20th century (slightly above 4 centuries later). The paper used historical sources which may not provide robust results. The analysis is important for the development of the microfinance industry. Knowledge of microfinance historical antecedents is likely to contribute to our understanding of the current microfinance sector conditions in the country, thus influencing policy. Most papers, when narrating the history of microfinance start from the 1970s when Yunus started microcredit programs in Bangladesh. This history is not wholly true because Yunus did not start from zero, microfinance was only re-kindled by Yunus but it has had a long and old history. This paper argues that the roots of microfinance go before the 1970s.
\end{abstract}

Keywords: Microfinance, microcredit, historical antecedents, Zimbabwe.

\section{Introduction}

Microfinance evolved and expanded from the narrow field of microcredit (Helms, 2006; Elahi and Rahman, 2006; Henry et al, 2003). Microcredit is a narrow view of giving small loans to poor people while microfinance is a more comprehensive concept that encompasses a wide range of financial services for poor people. Helms (2006) gives a historical evolution of microcredit and eventually microfinance.

The ideas of microfinance date back to the $15^{\text {th }}$ century when pawn shops were established in Europe as alternatives to usurious money-lending. In the 1700s, the Irish Loan Fund System was established in Ireland. The 1800s saw the emergence of financial cooperatives in Germany. These were developed by Friedrich Wilhelm Raiffeisen and his supporters. These cooperatives were developed to improve the welfare of the rural and urban poor people. In 1895, Indonesia developed the idea of banks for poor people by establishing the Indonesian People's Credit Banks.

Savings and credit activities began to appear in Latin America and elsewhere in the early 1900s (Helms, 2006). New banks for the poor were developed to mobilize 'idle' savings and promote investments. However, the banks were not owned by the poor but by government agencies and private banks. Unfortunately, Helms laments, the institutions were inefficient and corrupt. The evolving idea was developed into agricultural credit by governments and donors between the 1950s and the 1970s (Helms, 2006). Agricultural credit had an aim of raising productivity and incomes of small and marginalized farmers through the provision of credit. Government owned financial institutions were offering credit at below-market interest rates. This had detrimental effects on the financial institutions as they failed to recover costs. Furthermore, customers viewed loans from government agencies as gifts and this impacted negatively on the repayment rate. The problem is still prevalent in developing countries where politicians take advantage of this loophole to win the hearts of the electorate. In other situations, credit was not reaching the poor; instead it ended up in the hands of rich and influential farmers (the rural elites).

The "microcredit" concept was re-born in the 1970s. It then attained world-wide recognition when Muhammad Yunus started (as a pilot project with his graduate students at Chittagong University in 1976) making small loans to the poor villagers in Bangladesh (Khandker, 1998; Zeller and Sharma, 1998 \& 2002; Zeller and Meyer, 2002; Robinson, 2001; Yunus, 2003 and 2004; Amendariz de Aghion and Morduch, 2005). Microcredit received worldwide attention when people started welcoming it as a poverty alleviation strategy. Results from the popular Grameen model were encouraging (Kandker, 1998; Karmakar, 1999; Robinson, 2001; Armendariz de Aghion and Morduch, 2005; Menon, 2006). The 
Grameen model used the group lending methodology as a way of delivering financial services to the poor people. Given that the poor lack physical collateral security, the model advocated for what it called "social collateral" which involved a peer pressure strategy among group members. The bank realized an average loan recovery rate of more than 95 per cent (Khandker, 1998). This was contrary to conventional wisdom that the poor cannot be reliable customers in finance (Carr and Yi Tong, 2002; Helms, 2006). Low-income or poor people are marginalized because they lack the credentials and physical collateral that is required by traditional financiers (the banks).

Learning from the Grameen Bank model, microcredit expanded (in the 1980s) to Latin America, India, Brazil and Africa. Organizations such as ACCION International (which began in Latin America), the Self-Employed Women's Associations (SEWA) bank in India, BancoSol in Brazil, K-Rep and Equity Banks in Kenya emerged. These institutions are still in existence today and are expanding their operations.

The realization of structural barriers to providing savings and credit service to the poor (Elahi and Rahman, 2006) motivated the emergence of microcredit programs. Structural barriers facing the poor people include information asymmetries, lack of collateral, high transaction costs, high risk and systematic market bias (Elahi and Rahman, 2006). Proponents of microcredit such as Yunus $(1998,2003$, and 2004) and FINCA (2007), suggest that these barriers could be overcome through the provision of small loans to the poor. The loans will then help them to develop their businesses and pull them out of poverty traps or break out of the poverty 'vicious cycle' and enter a 'virtuous cycle'. The Grameen Bank's success in reaching the poor and high loan recovery attracted world-wide attention. As mentioned earlier, many countries started to replicate the Grameen Bank's group-lending methodology for providing loans to the poor and lowincome groups. For example, in Indonesia, the Bank Rakyat was established to serve poor people. The bank proved that the poor can be good customers in finance.

The term "microcredit" was getting replaced by "microfinance" in the early 1990s (Helms, 2006). The success of microcredit programs led to the 1997 microcredit summit that attracted 2900 delegates from 137 countries representing 1500 organizations the world over. The term micro-finance then emerged and took center stage in the late 1990s (Elahi and Rahman, 2006:477; Edward \& Olsen, 2006). Elahi and Rahman explain the functional and conceptual differences between "microcredit" and "microfinance".

Microcredit involves the provision of small loans to the poor (credit as the missing piece). On the other hand, microfinance encompasses a range of financial and non-financial services that include savings, insurance, money transfers, training and social engagements over and above credit. Today, the provision of microfinance ranges from traditional informal suppliers to commercial banks. Commercial banks are starting to enter the microfinance sector so as to provide financial services to the poor. Traditional banks are slow to take up the challenge of providing credit to the poor people because they rate them as risky borrowers. However, the current focus is now on researching to find out ways of building an inclusive finance system that works for the poor (Rhyne, 2013; Helms, 2006; Rhyne, 1998). This study is poised to contribute towards the research focus.

Poor people lack physical collateral security, which is an integral traditional requirement needed by lenders. However, the proponents of microfinance have discovered that the poor can pay back. The Grameen Bank's group lending methodology identified 'social collateral security' that the poor people possess (Khandker, 1998). Empirical evidence from the Grameen Bank experience has recorded about 95\% repayment rate by the poor borrowers. Khandker notes the following;

Grameen Bank, founded in 1976 as a project and transformed into a specialized bank in 1983, is the best-known micro-credit program. By 1994 it had mobilized more than 2 million members, 94 percent of them women, and achieved a loan recovery rate of more than 95 percent (Khandker, 1998:3).

IFAD (2004) states that in countries as diverse as Bangladesh, Benin and Dominica, repayment rates are as high as 97 per cent. This strengthens Khandker's statistical evidence about high repayment rates by microfinance participants although they are regarded 'unbankable' in the traditional financial sector. This high rate was achieved by the bank's group-lending methodology that took advantage of the social capitall ${ }^{1}$. Access to financial resources has been hailed as an intervention for poverty alleviation.

In 1984, John Hatch ${ }^{2}$ came up with a new model called "village banking". This is a unique and influential method for delivering non-collateralized small loans, savings and other financial services to the poor worldwide (FINCA, 2007).

\footnotetext{
${ }^{1}$ Social Capital refers to connection within and between social networks. It also refers to goodwill, fellowship, sympathy and social intercourse in a community. It is the 'cement' that keeps the social fabric intact. (see Vermaak ,2009 for a comprehensive articulation of social Capital)

2 John Hatch in the inventor of the "Village Banking Model" and founder of FINCA(a global microfinance institution). He is a co-founder of the Global Micro-credit Summit.
} 
Village banking is gaining momentum and is proving to be an effective tool for poverty alleviation among the poor people. The poor people were being organized into groups, giving them the power to collectively disburse, invest and collect loan capital as they saw fit. This program then gained the name "Village Banking." Zimbabwe has its own microfinance history that forms part of the international developments of the sector.

\section{The Evolution and Development of Microfinance in Zimbabwe.}

The Zimbabwean microfinance sector dates back to the 1960s when people were mobilized into groups to form savings clubs. Even before these groupings, people had other sources of credits such as friends and relatives. This is a universal phenomenon which is not exclusive to Zimbabwe. According to Adams and Raymond (2008) informal credit sources, such as family members and friends, moneylenders, commercial agents and group-based Rotating Savings and Credit Associations (ROSCAs) have been providing peasants with credits for centuries. This applies to the Zimbabwean scenario as well. In Zimbabwe private moneylenders offer exorbitant or usurious loans called 'chimbadzo' (meaning exploitative lending).

Raftopoulos and Lacoste (2001) and Bond (1998) narrate that the Zimbabwean microfinance dates back to 1963 when the Catholic Missionary initiated the Savings Development Movement (SDM). The organization focused on microsavings mobilization by rural women. The women operated in groups thus SDM savings club was established. The club's sustenance was based upon financial savings generated by club members.

Savings clubs grew in numbers from 30 in 1970 to 1500 in 1974 as established by Raftopoulos and Lacoste. They further reported that during the same period, club membership increased from 2000 to 3000 . They also noted that the savings clubs reached 3000 in 1975 with 60000 active members. However, their activities were hampered by the liberation struggle activities (1976 to 1980). War is always an underdevelopment catalyst and it provides a fertile ground for inflation and other negative socio-economic forces. After the Zimbabwean independence (i.e. 1980) SDM was then registered as a cooperative (Bond, 1998; Bond and Manayanya, 2002 \& 2003).

The post-independence period created an enabling environment for the continuation of savings clubs that had been stopped in the previous years. Raftopolous and Lacoste note that savings clubs increased from 5000 in 1983 to 7000 in 1998. This remarkable increase was a clear sign of the demand for microfinance by the poor. In the early 1980s the Agricultural Finance Cooperation (AFC), a parastatal, was central in extending loans to small-holder farmers.

In a bid to support the mobilization of savings by the poor, the government established the National Association of Cooperative Savings and Credit Unions of Zimbabwe (NACSCUZ) in 1986. This was under the Ministry of Community Development and Women's Affairs. NACSCUZ's main aim was to provide technical support services to savings and credit cooperatives. Its other objectives were the provision of training, monitoring and evaluation of credit cooperatives.

The Economic Structural Adjustment Program (ESAP) era (1991-1995) created an environment that had serious repercussions on the poor. ESAP, among other things called for financial liberalization. This policy prescription led to an increase in interest rates, hence reducing the access to loans by the poor (Moyo, 1999). Due to increased government borrowing, removal of subsidies on basic goods, trade liberalization and devaluation, there was an increase in inflationary pressures in the country. These macroeconomic conditions posed a threat to micro-credit activities in the country. Liberalization in the financial sector created an environment that was not favorable to the poor as was noted by Moyo:

The increasingly competitive environment created by reforms has led to a much tougher approach by banks in terms of lending to the poor. It has always been hard for this group to get loans from banks. It is now more difficult. Collateral requirements have been maintained if not actually made stiffer in some cases as banks perceive the environment to be riskier. Even Development Banks which used to be more flexible and would look at project viability rather than short-term profitability, now tend to look at profitability (Moyo, 1999:3)

In 1996, the Self-Help Development Foundation (SHDF) was formed in place of the SDM. A micro-credit scheme was introduced by SHDF in the same year, which was meant to promote savings among the poor (Raftopoulos and Lacoste, 2001). The ESAP challenges invited initiatives from international NGOs (in 1997) such as Konrad Adenaur Foundation (KAF), CARE International and the Belgium based Association pour la developpement oar la recherché et l'action integree [" Association for the Development by Research and Integrated Action"] (ADRAI). The international NGOs gave financial support to SHDF's microcredit activities. Raftopoulos and Lascote observe that they promoted, among other things, the development of sound credit methodologies, improvement of governance and establishment of sustainable revolving funds. This kind of support is needed today for a full blown development of microfinance institutions so as to realize credible microfinance methodologies and sustainability. 
However, the SHDF idea faced criticism because of a number of challenges involved. Raftopoulos and Lacoste argue that credit to the poor creates problems such as lack of capacity to cope with credit. Rich people often have access to credit at the expense of the poor. Furthermore, most of the microfinance programs are financed by donors and people do not feel responsible about donor money. Donor money is frequently misused and borrowers are reluctant to pay back when they borrow. According to Raftopoulos and Lacoste (2001), the SHDF program showed impressive results between 1996 and 2000 through the support by USAID (through CARE), and ADRAI. Table 1 below shows the program's portfolio growth between 1996 and 2000.

Table 1: SHDF's Portfolio Growth 1996- 2000

\begin{tabular}{|c|c|c|c|c|c|c|}
\hline Year & 1996 & 1997 & 1998 & 1999 & 2000 & TOTAL \\
\hline Loans disbursed & 117 & 775 & 2315 & 4542 & 7097 & 14864 \\
\hline Total amount disbursed & 119800 & 1055600 & 4077900 & 11716854 & 31977346 & 48707900 \\
\hline
\end{tabular}

Sources: Raftopoulos and Lacoste (2001).

As shown in Table 1 above, loans disbursed increased steadily from 117 in 1996 to 7097 in 2000. The total amounts disbursed also increased from Z $\$ 119800$ in 1996 to Z\$31 977346 in 2000. This increase demonstrates the high demand for loans by the poor and low income groups. The political environment in Zimbabwe has had profound effects on microfinance activities, with the liberation struggle disturbing the progress and the recent political landscape negatively affecting microfinance activities. The following section gives a snapshot of political events in Zimbabwe and their implications on the economy in general and microfinance in particular.

\section{The Zimbabwean Microfinance Sector}

This sector remains underdeveloped and generally informal in Zimbabwe. Microfinance activities also face a number of challenges. However, they remain subdued with hyperinflation, (between 2000 and 2009) acute foreign currency shortages, high unemployment levels, high incidences of poverty and a decline in real incomes and standards of living. On the other hand the industrial base is also shrinking. The aforesaid conditions have made policymakers to divert their attention away from microfinance. This has had detrimental effects in the development of the microfinance sector that is meant to serve the poor.

The majority of rural Zimbabweans remain completely cut-off from the traditional banking services. The same was echoed by the Reserve Bank of Zimbabwe (RBZ) governor in his April 2007 Monetary Policy Statement (ZAMFI $\left.{ }^{3}, 2007\right)$. He pointed out that there was need to rope in the rural communities for inclusion into the financial system. According to ZAMFI, the per capita banking facility ratios in rural areas indicate unacceptable levels of financial exclusion of the rural populace. Despite the prohibitive macroeconomic environment, there is general consensus from government circles that microfinance can be used as a strategy for poverty alleviation in Zimbabwe. The situation on the ground suggests that the demand for microfinance resources is very high. This study also pays attention to the demand for microfinance in Zimbabwe.

\section{Demand for Microfinance}

Effective demand or simply demand is the willingness and ability that people have to acquire a commodity. In this case the commodity refers to microfinance services offered by different suppliers that may be formal (such as banks and MFIs), quasi-formal (such as NGOs) or informal (such as relatives and friends). A commodity is anything that has the ability to give satisfaction or utility to the purchaser. Microfinance resources are on demand because of their ability to meet the capital needs of the poor who are considered 'unbankable'. Robinson (2001:10) states that about 80 percent of the world's population has no access to formal sector financial services. This percentage is higher (about 95\%) in the developing countries as posited by Hailu (2008). Most of the demand for microfinance resources comes from those operating in the unregulated, informal sector of the economy (Robinson, 2001:11; 2002).

The informal sector is a manifestation of the failure of the formal sector to meet the needs and wants of the people.

${ }^{3}$ ZAMFI is Zimbabwe Association of Microfinance Institutions. The organization is made up of voluntary membership of microfinance institutions (MFIs). 
Therefore, they find refuge in the informal sector for employment incomes, assets accumulation and livelihoods. This sector is characterized with enterprises that; have non-legal status, lack authorized business location, have no standard forms of collateral security, are small in size and their business activities are risky. These characteristic features discourage banks to supply the sector with financial services. Traditional banks are not willing to take the risk because they rate the sector 'credit unworthy'. This scenario has created a huge gap that gets filled by private moneylenders who usually charge usurious rates of interest hence exploiting the vulnerable poor people. This is where the misconception of microfinance as a usurious product emerges. Many people thing that microfinance only means short loans by private money-lenders who are popularly known as 'loan sharks' because of their usurious acts.

The Zimbabwean economy is dominated by small to medium enterprises (SMEs). In 1998, an estimated 860000 micro and small enterprises were engaged in manufacturing, commerce and service activities. They generated selfemployment and jobs for about 25 percent of the Zimbabwean population (Barnes et al, 2001. See also Bakhoum et al. 1989 and Basu et al. 2004). As the crisis in Zimbabwe worsened, demand for loans remained high because people were relying on the informal sector for a living (Bell et al, 2002).

According to ZAMFI (2007), the unprecedented economic decline witnessed the emergence and growth of the informal sector in leaps and bounds. ZAMFI also quoted the Reserve Bank of Zimbabwe (RBZ) citing that in 2005, the formal sector employment accounted for 16 percent of the labor force. The informal sector accounted for 40 percent and the communal sector for 44 percent. The RBZ also cited that the informal sector was responsible for the livelihoods of about 80 percent of the population (until 2007) following the shrinkage of the formal sector since 2000.

The ESAP period (1991-1995) led to retrenchments and downsizing by the formal sector. These casualties made people to look for new economic opportunities that were only visible in the informal sector. The sector managed to absorb the retrenched and this made it very important because it provided a quick alternative to those who had been laid off. Micro-entrepreneurs have become a vibrant part of the Zimbabwean economy. Micro-enterprises are a vital source of income, particularly for the rural poor. After recognizing the important contribution of the informal sector, the government of Zimbabwe established the Ministry of Small and Medium Enterprise Development that was mandated to promote the small businesses sector. The growth of the informal sector is followed by simple economic logic that explains high demand for microfinance in Zimbabwe.

Rural areas are seriously underserviced by the traditional providers of financial services. Traditional banks argue that it is problematic to provide financial services to the rural areas because of their remoteness. Servicing rural remote areas comes with very high transaction costs hence raising sustainability questions. The cost per dollar or rand lent is very high, making it unsustainable. Moreover, rural areas have information asymmetry leading to moral hazard ${ }^{4}$ problems. This distortion in the rural economies is explained by the intrinsic limitations of the price system in the rural areas. Hoff et al. (1993), identify adverse selection and moral hazard as common rural sector problems. Adverse selection ${ }^{5}$ refers to the problem of sorting or choosing borrowers (customers) whose quality is not known (quality uncertainty). Moral hazard arises when a customer takes action to maximize own welfare that is to the detriment of others. This also applies to the Zimbabwean rural areas hence the emergence of a disparity between demand for and supply of microfinance.

\section{Supply of Microfinance}

Microfinance market structures vary from one country to the next depending on financial development, policy environment and level of economic development. In Zimbabwe microfinance is provided by banks, Post Office savings Bank (POSB), microfinance institutions (MFIs), associations (ROSCAs ${ }^{6}$ ), Regular (non-rotating) Savings and Credit Associations- RESCAs, non-governmental organizations (NGOs), relatives and friends, and private money-lenders. The government is also a supplier of microfinance resources to the rural poor; however the latter has been politicized. Microfinance services that are provided for agriculture and seasonal loans are often available in kind. For example, the government's 'maguta/ inala program' (bumper harvest program) of 2007, with farmers getting diesel, seeds, farm

\footnotetext{
4 In other words moral hazard in lending refers to situations where lenders cannot observe either the effort made or action taken by the borrower, or the realization of project returns. This could be ex ante or ex post (Armendariz de Aghion and Morduch, 2005).

5 see Armendariz de Aghion and Morduch, 2005:29 for a clear explanation of 'adverse selection'.

${ }^{6}$ ROSCAs are Rotating Savings and Credit Associations. They are essentially a group of individuals who make regular cyclical monetary contributions into a savings pool. Group members borrow money from the pool at a given rate of interest. They are referred to as banks for the poor. RESCAs are Regular (non-rotating) Savings and Credit Associations-members contribute but all do not necessarily borrow (Robinson, 2001:50).
} 
implements, fertilizers and herbicides. Unfortunately, the program was hampered by drought that negatively affected agricultural production. Small-holder famers were not able to repay the Government of Zimbabwe (GOZ) making it to lose lots of money in unpaid loans (bad debts). Government efforts to support the microfinance sector are complimented by the donor community.

According to UNDP Zimbabwe (2008), the microfinance sector experienced a phenomenal growth in 2007 in tandem to the growth of the informal sector as the formal sector faced serious challenges. UNDP's report further state that 309 microfinance institutions and micro lending institutions (MLIS) were registered with the Reserve Bank of Zimbabwe (RBZ). However, the worsening problems of the mid-2008 left approximately 150 out of 309 MFIs and MLIs operational representing about $48 \%$. These were mainly affected by the hyperinflationary pressures that characterized the period. An inappropriate legal framework also contributed to the constraints.

\section{Donor Interventions in the Sector}

Since 1980, many international donors stepped up their involvement in the microfinance sector (Pearson and Hungwe, 1997). A number of international donor organizations were involved, since independence, in the support of small to medium (SME) programs. These efforts were meant to close the supply gap left open by the traditional financial sector. The donor agents included Australian Agency for International Development (AUSAID), Austrian Government, and British Department for International Development (DFID), Canadian International Development Agency (CIDA), and German Development Co-operation (GTZ). The other organizations involved include Hivos Foundation, Konrad Adanauer Foundation (KAF), Royal Netherlands Embassy, United Nations Development Program, United States Agency for International Development (USAID), Norwegian People's Aid, African Development Foundation (ADF), Oxfam, Catholic Development Commission (CADEC), CARE, NORAD and Catholic Relief services (CRS). The list is not exhaustive.

Donor support activities included capacity building, human resources development, technical assistance, monitoring and evaluation, training (staff and board members) and the revolving loan funds. Unfortunately, in July 2008 a number of donors were banned by the government. This was the hardest blow ever to the growth of microfinance in Zimbabwe. Local NGOs and banks also support the microfinance sector.

\section{Local NGOs and Banks Intervention}

Commercial banks that support the microfinance initiative include Barclays Bank, Commercial Bank of Zimbabwe (CBZ), Agricultural Bank of Zimbabwe (AGRIBANK), Post Office Savings Bank (POSB), and Kingdom Bank (through its subsidiary Microking ${ }^{7}$ ). This list is not exhaustive (Pearson and Hungwe, 1997). These banks have facilities of giving relatively small loans to SMEs.

Local NGOs include Credit Against Poverty-Masvingo (CAP), Dondolo Mudonzvo, Environment and Development Activities (ENDA), National Association of Cooperative Savings and Credit Unions of Zimbabwe (NASCUZ), Organization of Rural Associations for Progress (ORAP), Phakama Savings and Credit Cooperative Society, Self-Help Development Foundation (SHDF), Zambuko Trust, and Zimbabwe Ecumenical Church Loan Fund (ZECLOF). Also adding to the list is Zimbabwe Project Trust (ZPT), Zimbabwe Women's Bureau (ZWB) and Zimbabwe women's Finance Trust (ZWFT), and Rural Unity for Development Organization (RUDO), Catholic Development Commission (CADEC).

These organizations act as conduits that receive money from donors and pass it to the poor people in the informal sector. They run revolving loan funds so as to remain sustainable. However, their sustainability strategies were eroded by Zimbabwe's hyperinflationary environment. Government organizations also play an important role in supporting the poor with microfinance services.

\section{Government Involvement}

The Government of Zimbabwe (GoZ) assists the SMEs and small holder farmers through its parastatals such as AGRIBANK, Small Enterprise Development Corporation (SEDCO), Social Development Fund (SDF) [under the Ministry of Public Service, Labor and Social Welfare]. The Ministry of Gender and Youth Development also gives loans to women and youth for their developmental projects meant to pull them out of poverty (Pearson and Hungwe, 1997). This initiative resulted from swelling unemployment among the youth and was also used as an empowerment strategy for women.

${ }^{7}$ MICROKING Finance is the micro enterprise finance division of Kingdom Bank Ltd. 
The government's involvement cannot end by providing loans to the poor. It is its responsibility to create a supportive legal environment. Private moneylenders are viewed as exploitative monopolists who systematically squeeze the poor (Armendariz de Aghion and Morduch, 2005:27). The moneylenders enjoy local monopoly power because potential competitors cannot enter the market due to lack of information (information asymmetry) and connections. High interest rates continue to worry governments today. This is not exclusive to Zimbabwe. Armendariz de Aghion and Morduch (2005:28), note that Siaamwala et al, 1990, reported 120 percent interest rates in Thailand; Aleem (1990) found them to be between 8 and 200 percent in Pakistan; and Steel et al (1997) established that the interest rates were 50 percent points higher than formal sector rates in Ghana, Malawi, Nigeria and Tanzania.

The situation of high interest rates forces governments to give cheap credit to the poor people. This has not achieved much in pulling people out of poverty. Ironically, cheap credit has been criticized for contributing towards the underdevelopment of rural areas. Adams et al (1984), in their book Undermining Rural Development with Cheap Credit, unequivocally pointed out that, low interest rates undermine microfinance and rural development. The Consultative Group to Assist the Poorest (CGAP) in 1996 also hints that interest rates charged should promote the sustainability of MFIs (Armendariz de Aghion and Morduch, 2005:52). This suggests for the commercialization of microfinance as opposed to subsidization. Above all, the government should ensure a supportive legal environment for the efficacy of microfinance. What is the situation in Zimbabwe?

\section{Zimbabwean Legal Environment and Microfinance}

The Reserve Bank of Zimbabwe (RBZ) is responsible for monitoring the monetary policy (RBZ, 2004; RBZ, 2005; ZAMFI, 2005). It also administers the operations of the financial sector and is responsible for ensuring a sound and sustainable financial system. MFIs form part of the financial sector hence they are under the control of the RBZ. Their operations are guided by the Money-Lenders' Act. MFIs are required to be registered with the RBZ and are given operating licenses that are renewed annually. It becomes the responsibility of the RBZ to create an enabling legal environment in support of the microfinance sector. Currently, the legal environment is not very supportive of the microfinance sector.

MFIs have legal incapacity to raise savings. The Moneylenders' Act provides the legal framework for all non-bank intermediaries engaged in lending activities. It does not allow NGOs to mobilize savings (Raftopoulos and Lacoste, 2001). NGOs that are willing to expand operations in the microfinance sector cannot facilitate savings mobilization unless they are registered under the Company and Banking Act. The financial requirements of this Act were in 2005 toughened in order to deter opportunistic newcomers. The new Act states that the minimum paid up equity capital must be $Z \$ 100$ million (which was equivalent to USD10 000). This was completely out of reach of Zimbabwean MFIs. They further note that, nevertheless, the new Minister of Finance (in office since June 2000) sent positive signals to the microfinance industry, since its role in supporting the informal economy is increasingly acknowledged.

As noted by ZAMFI (2005), microfinance is widely acknowledged as a viable strategy for promoting informal sector business activities. The importance of the informal economy in serving as a safety net in times of deep economic crisis can never be overemphasized. The introduction of a new "microfinance" Act, adapted to the specific capacities and needs of MFIs, is actually one of the main responsibilities of the Zimbabwean Association of Microfinance Institution (ZAMFI), but much has still to be done before a new legislation comes into effect (Raftopoulos and Lacoste, 2001). ZAMFI lobbies for the crafting (by government) of a supportive microfinance legal policy framework. The policy framework will go a long way in promoting MFI activities. The background above shows that there is deep and wide poverty in Zimbabwe hence the need for a strategy to fight it from the grassroots.

\section{Microfinance Industry in a Crisis Zimbabwe}

The Zimbabwean economy faced a crisis period due to the deteriorating socio-economic and political conditions. Thus the economic fundamentals suffered mainly from political challenges that were experienced between 2000 and 2009 . The microfinance sector almost disappeared because of the harsh economic environment.

\section{Current Policy Trends in the Microfinance Sector}

There is a plethora of policy orientations that impact (positively or negatively) on microfinance activities. But more importantly, there are three policy actions that should be fine-tuned to promote microfinance. These are macro-economic stability, liberalized interest rates and appropriate banking and supervisory practices (Adams and Raymond, 2008). Due 
to the challenges that the Zimbabwean economy has experienced, the government noticed the resilience that was displayed by small to medium enterprises (SMEs) both in the formal and informal sector. The informal sector ballooned as formal businesses were collapsing due to the harsh economic conditions. So the informal sector played a significant role in the economy during the Zimbabwean economic crisis (Makina, 2010; Mackochekanwa and Kwaramba, 2010; Makochekanwa, 2007. The economy survived on SMEs (both formal and informal) as drivers of economic activities that sustained the livelihoods of the people. This realization prompted the government to address questions about an enabling environment for promoting the microfinance sector.

The microfinance sector in Zimbabwe has been operating without a policy for decades. A piece of legislation that has been in use is the Money Lenders' Act that was promulgated by the government. However, the Act has not been supportive enough to encourage the growth of the sector (ZAMFI, 2005; UNDP Zimbabwe, 2008). As discussed earlier, the RBZ in 2005 put in place a Consultative National Task Force to look into the development of a National Microfinance Policy. In 2008, the policy was developed to ensure supervision of the sector. The microfinance policy is a welcome development which was being pushed for by ZAMFI (the main stakeholder). The National Microfinance Policy was developed by the National Microfinance Task Force on microfinance. Members of the task force were Government ministries, apex organizations of microfinance and moneylenders, microfinance institutions, development partners, and the RBZ (RBZ, 2008). The policy development process started with the establishment of a task force in 2005 whose main mandate was to develop mechanisms that would guide the development of a sustainable microfinance industry.

That task force started by commissioning a survey through a consultancy firm (Ernst \& Young) between December 2005 and March 2006. The survey found out that about $30 \%$ of the economically active population is serviced by the formal financial system while $70 \%$ are excluded. This group is often serviced by the semi-formal or informal financial sectors. The major output of this process was the formulation of the National Microfinance Policy in 2008. According to RBZ (2008), the main objective of the policy is to promote a vibrant microfinance sector that would be adequately integrated into the mainstream financial system and provide the stimulus for growth and development. Specific policy objectives are:

- to promote the development of a robust, inclusive financial sector;

- to promote synergy and mainstreaming of the informal sub-sector into the national financial system;

- to enhance service delivery by microfinance institutions to the economically active poor and SMEs;

- to contribute to rural transformation; and

- to promote linkage programs between commercial banks, building societies, development banks, specialized institutions and microfinance banks and other microfinance stakeholders (National Taskforce on Microfinance, 2008:11).

The Southern Africa Microfinance \& Enterprise Capacity Enhancement Facility (SAMCAF) carried out a SADC study in 2008 synthesized the salient features of the Zimbabwean National Microfinance policy as follows:

- Creation of an enabling regulatory environment supportive of sustainable microfinance initiatives and infrastructure through the establishment of microfinance banks (deposit-taking);

- Integrating microfinance into the formal financial system to ensure permanent access to financial services on a sustainable basis;

- Development of performance standards for monitoring of microfinance institutions;

- Setting up an appropriate capacity building programmes for the microfinance sector to bridge the technical skills gap, especially among microfinance practitioners, regulators and apex organisations.

- Establishment of a credit reference bureau to improve the flow of information, enhance credit risk management practices and aid decision making on current and potential microfinance clients. (SAMCAF, 2008:35).

The National Microfinance policy sets a clear direction, however the government needs to expedite the process of developing and adopting an appropriate regulatory and supervisory framework to enhance vibrancy in the sector. The microfinance sector eagerly awaits the final adoption of the policy to allow the sharpening of innovative mechanisms for the growth of the sector in Zimbabwe.

\section{Conclusion}

The government of Zimbabwe followed some policy episodes since the attainment of independence in 1980. They can be categorized into the 'centralist policies' (1980 to 1990), 'market oriented policies' from 1991 to 2000 and the 'crisis period policies' of 2000 to 2009. Most of the policies were meant to address poverty but very little was achieved because of 
challenges at macro-level. Micro-level policy strategies such as microfinance failed to receive attention after a long time. Recently, in Zimbabwe, the RBZ managed to come up with a National Microfinance Policy that is meant to regulate and support the sector for sustainable operations. The evolution and developments of microfinance in Zimbabwe show that he demand for microfinance is higher than the supply hence the existence of a gap between demand and supply. Microfinance services are supplied by private money-lenders, government, NGOs, and informal sources such as friends and relatives. The government of Zimbabwe has been criticized for failing to articulate the two policy categories.

\section{References}

Adams, D.W., H.G. Douglas, and J.D von Pischke, eds. (1984). Undermining Rural Development with Cheap Credit. Boulder, CO: Westview Press.

Adams, J. and F. Raymond. (2008). "Did Yunus Deserve the Nobel Peace Prize: Microfinance or Macrofarce?". Journal of Economic Issues, vol.XLII, No.2, p435-443, June 2008. www.find.galegroup.com (accessed 24 July 2008).

Armendariz de Aghion, B. and J. Morduch. (2005). The Economics of Microfinance. London: Massachusetts Institute of Technology.

Bakhoum, I., H. Bhaskara, C. Chimbano, M.E. Gonzalez, W. Ogan, H. Ogola, A. Quinoes, J. Rahaman, N. Sedeque, G. Venkatramani, M. Wanigasundara. (1989). Banking the Unbankable: Bringing Credit to the Poor. London: The Panos Publication Ltd.

Barnes, C., E. Keogh, and N. Nemarundwe. (2001). Microfinance Program Clients and Impact: An Assessment of Zambuko Trust, Zimbabwe, Assessing the Impact of Microenterprises Services (AIMS), Management systems International. Washington D.C. [Online] Available: www.microlin ks.org/ev_en (23 July 2008).

Basu, A., R. Blavy, M. Yulek. (2004). "Microfinance in Africa: Experience and Lessons from Selected African Countries", Working paper no. WP/04/174, Washington, D.C: International Monetary Fund.

Bell, R., A. Haper and D. Mandivenga . (2002). Can Commercial Banks Do Microfinance? Lessons from the Commercial Bank of Zimbabwe and the Co-operative Bank of Kenya, Small Enterprise Development Journal (SED), vol. 13(4), December 2002. [Online] Available:ww.dai.com/pdf/can_commercial_banks_Do_Microfinance.pdf. (15 September 2008).

Bond, P. (1998). Uneven Zimbabwe: A Study of Finance, Development and Underdevelopment. Trenton, NJ: Africa World Series.

Bond, P. and J.M. Manyanya. (2002). Zimbabwe's Plunge: Exhausted Nationalism, Neoliberalism \& Search for social justice. Pietermaritzburg: University of natal Press.

Bond. P and J.M. Manyanya. (2003). Zimbabwe's plunge: Exhausted Nationalism, Neoliberalism, and The search for social justice. South Africa: University of Natal Press

Carr, J.H. and T. Zhong Yi, eds. (2002). Replicating Microfinance in the United State. USA: Fannie Mae Foundation.

Edward, P. and W.K. Olsen. (2006). "Paradigms and Reality in Micro-Finance: The Indian Case." Perspectives on Global Development and Technology vol 5:1-2. India

Elaihi Qudrat-I, K. and M.L. Rahman. (2006). Micro-credit and micro-finance; Functional and Conceptual Differences, Development in Practice, Volume 16, Number 5, August 2006. Great Britain: Oxfam. [Online] Available: www.ebscohost.com (7 August 2008).

FINCA. (2007). The History of FINCA . [Online] Available: http://www.villagebanking.org/site/c.erKPI2PCloE/b.2604291/k.99B5 IFINCAs_History.htm . (25 September 2005).

Hailu, D. (2008). Equitable Access to Financial Services; Is Microfinance Sufficient? International Poverty Centre, July 2008 Number 59 (One pager). [Online] Available: www.undp-povertycentre.org. (26 July 2008).

Helms, B. (2006). Access for all: Building inclusive Financial Systems. USA: The International Bank for Reconstruction and Development/The World Bank's Consultative Group To Assist the Poor (CGAP).

Henry, C., M. Sharma, C. Lapenu and M. Zeller. (2003). Microfinance Poverty Assessment Tool. Washington DC: CGAP (Consultative Group to Assist the Poor)/ International Bank for Reconstruction and Development (The World Bank).

Hoff, K., A. Bravernman, J.E. Stiglitz, eds. (1993). The Economics of Rural Organisation, Theory, Practice and Policy. USA: World Bank.

IFAD. (2004). Microfinance: Macro-benefits. Italy: IFAD. [Online] Available: www.ifad.org/ruralfinance. (15 September 2007).

IFAD. (2007). Rural Poverty Portal-Rural Finance and Rural Poverty. Italy. IFAD: [Online] Available: www.ifad.org/ruralfinance. (10 September 2007).

Karmakar, K.G. (1999). Rural Credit and Self-Help Groups: Micro-Finance Needs and Concepts in India. London: SAGE.

Khandker, R. S. (1998). Fighting Poverty with Micro-credit: Experience in Bangladesh. USA: Oxford University and The World Bank.

Makina, D. (2010). Historical Perspectives on Zimbabwe's Economic Performance: A Tale of Five Lost Decades. Journal of Developing Societies (2010) 26:99-123. Washington D.C: SAGE Publications.

Makochekanwa . A and Kwaramba. M. (2010). Dwindling Access to basic Services in Zimbabwe. Department of Economics, University of Pretoria. Munich Personal ReEEc Archive(MPRA). [Online] Available: http://mpra.ub.uni-muenchen.de/28271/. ( 25 March 2011)

Makochekanwa, A. (2007). A Dynamic Enquiry into the Causes of Hyperinflation in Zimbabwe. Department of Economics Working Paper Series. South Africa: University of Pretoria.

Menon, N. (2006). "Non-Linearities in Returns to participating in Grameen Bank Programs". Journal of Development Studies, Vol. 42, N0 8, 1379-1400. USA: Routledge.

Moyo, T. (1999). Impact of Financial Sector Liberalization. Harare: Poverty Reduction Forum/SAPRIN.

National Task Force on Microfinance (NTFM). (2008). The National Microfinance Policy. Reserve Bank of Zimbabwe (RBZ) Harare: 
[Online] Available: www.rbz.co.zw/pdfs/200\%20MPS/bl_microfinanc policy.pdf. (28 September 2009).

Pearson, R. and P. Hungwe. (1997). UNDP Microfinance Assessment Report for Zimbabwe. Prepared as a component of the MicroStart Feasibility Mission. Harare. [Online] Available: www.microfinancegateway. 29 November,2007).

Raftopolous, B. (2001). The state and Poverty Reduction Policies in Zimbabwe, 1980-97. In Wilson, F., N. Kanji, and E. Braathen, eds. 2001. Poverty Reduction: What Role for the State in Today's Globalised Economy? CROP International Studies in Poverty Research. London: UK ZED Books.

Raftopoulos, B. and J. Lacoste. (2001). From Savings Mobilization to Microfinance: A Historical Perspective on the Zimbabwean Self Help Development Foundation (SHDF). Food and Agricultural Organization (FAO) Paper presented at the International Conference on "Livelihood, Savings and Debts in a Changing World: Developing Sociological and Anthropological Perspectives". The Netherlands: Wageningen. [Online] Available: http://www.fao.org/wairdocs/ad706e/ad706e01.htm. (10 September 2008).

RBZ. (2004). Monetary Policy Statement: The Second Quarter to 30 June 2004. Harare: Reserve Bank of Zimbabwe.

RBZ. (2005). Third Quarter Monetary Policy Statement. Harare: Reserve Bank of Zimbabwe.

RBZ. (2008). Monetary Policy Statement. Harare: Reserve Bank of Zimbabwe.

Rhyne, E. (1998). The Yin and Yang of Microfinance: "Reaching the Poor and Sustainability". In Robinson, S.M. 2001. The Microfinance Revolution. Washington, D.C: The World Bank and Open Society Institute. 2001, p24-25.

Rhyne, E. (2013). Financing Smallholder Farmers With Fairtrade Access Fund. Centre for Financial Inclusion. USA

Robinson, S. M. (2001). The Microfinance Revolution: Sustainable Finance for the Poor. Washington, D.C: The World Bank and Open Society Institute.

Robinson, S. M. (2002). The Microfinance Revolution: Lessons from Indonesia, vol 2. Washington, D.C: The World Bank and Open Society Institute.

SAMCAF. 2008. Microfinance and Poverty Reduction in the SADC Region: Challenges and Opportunities. Unpublished Final Report of Study. Harare, Zimbabwe. SAMCAF. e-mailed copy.

UNDP. (2008). Comprehensive Economic Recovery in Zimbabwe: A Discussion Document. Zimbabwe: UNDP.

Vermaak, J. (2009). Social Capital as a Mechanism for Socio-economic Development Amongst Agricultural Producers in Vhembe, Limpopo. AFRICANUS Journal of Development Studies, Volume 39 (1) 2009. South Africa: UNISA Press.

Yunus, M. (1998). Essays On Science and Society: Alleviating Poverty Through Technology. Science 16 October 1998, Volume 282 no. 5388,pp. 409-410. [Online] Available: www.sciencemag.org/cgi/content/short. (3 June 2010).

Yunus, M. (2003). Halving Poverty by 2015-We can Actually Make It Happen. The Round Table, 92:370,363-375. Informa Ltd. UK. [Online] Available: http:www.informaworld.com/smpp/title content=t713448095. (03 June 2010).

Yunus, M. (2004). Grameen bank, Microcredit and Millennium Development Goals. Economic and Political Weekly, Vol.39, No. 36 (Sep. 4-10, 2004), pp. 4077-4080. [Online] Available: http://www.jstor.org/stable/4415509. (03 June 2010).

ZAMFI. (2007). Microfinance Monitor, Issue No. 6; December 2007. Harare, Zimbabwe: The official Newsletter. [Online] Available: http://www.jcc.com.na/files/microfinance\%20monitor. (27 January 2008).

Zeller, M. and L. R. Meyer, eds. (2002). The Triangle of Microfinance: Financial sustainability, Outreach, and Impact. Baltimore and London: The International Food Research Institute, John Hopkins University Press.

Zeller, M. and M. Sharma. (1998). Rural Finance and Poverty Alleviation. Food Policy Statements. IFPRI Publication: Food Policy Statement 27. [Online] Available: www.ifpri.org/pubs/fps/fps27.htm . (23 September 2007).

Zeller, M. and M. Sharma. (2002). 'Access to demand for financial services by the rural poor: A multicounty synthesis'. In Zeller, M. and L. R. Meyer, eds. 2002. The Triangle of Microfinance: Financial sustainability, Outreach, and Impact. Baltimore and London: The International Food Research Institute, John Hopkins University Press. 